\title{
EMPOWERMENT W ŚWIETLE BADAŃ DOTYCZACYCH ZAUFANIA W ORGANIZACJACH
}

DOI: $10.33141 /$ po.2020.11.03

\section{Zbigniew Malara, Janusz Kroik}

\section{Wprowadzenie}

$\mathrm{E}$ mpowerment (E) jest jedną ze stale rozwijających się współczesnych koncepcji zarządzania personelem (ZZL) i jest zwykle kojarzona $\mathrm{z}$ pozytywnym wzmacnianiem potencjału pracowników lub/i ich upełnomocnianiem (Czubasiewicz, Grajewski, 2018, s. 154). W rzeczy samej proces polega na skutecznym zachęcaniu pracowników do wykonywania przez nich zadań i wypełniania ról organizacyjnych. W literaturze przedmiotu podkreśla się, że warunkiem powodzenia $\mathrm{w}$ rozwijaniu E jest konieczność zmian w organizacji pracy i przymus redefinicji zachowań menedżerskich, które muszą być ukierunkowane na podnoszenie samodzielności i autonomii pracowników na wszystkich stanowiskach organizacji i instytucji.

Empowerment można rozpatrywać $\mathrm{z}$ różnych punktów widzenia, na przykład $\mathrm{z}$ perspektywy składowych odpowiadających za wzrost powodzenia (efektywności i skuteczności) wykorzystywania tego podejścia. W pracy H. Czubasiewicz i P. Grajewskiego (2018, s. 155) wyróżnia się pięć takich składowych, to jest: Nachylenie menedżerów na zwiększanie samodzielności podwładnych (NM); Zwiększanie samodzielności pracowników w działaniach na stanowiskach pracy (SP); Uczenie się samodzielności pracy (US); Identyfikacja i rozwój pracowników (RP); Wykorzystanie partycypacji pracowników (PP). Składniki te mogą stanowić przesłanki dla prowadzonej przez organizację polityki personalnej nastawionej na koncepcję E. Innym wykorzystywanym wyznacznikiem, na przykład na potrzeby diagnozy specyfiki koncepcji E, jest wyróżnianie pięciu wymiarów nazwanych $\mathrm{w}$ języku angielskim self-eficiency, self-determination, personal conseqency, meaning oraz trust (Gkorezis i in., 2001, s. 84; Czubasiewicz, Grajewski, 2018, s. 156). Propozycje te zostaną uwzględnione $\mathrm{w}$ niniejszej pracy.

Badacze koncepcji E wskazują na występowanie odmienności w akcentach, jakie w całym okresie jej stosowania (występowania, obecności) charakteryzują dany etap jej rozwoju. Aktualnie podkreśla się i wskazuje na kierunek obliczony na wzmacnianie innowacyjności i kreatywności pracownika działającego w ramach jego pełnomocnictw. Rozwiązania szczegółowe (sytuacyjne) wpływające na ten kierunek mogą współtworzyć specyfikę danego przedsiębiorstwa, przy czym podstawowe kanony koncepcji muszą być zachowane. Podstawowym spoiwem dla E jest kultura oparta na zaufaniu (Krawczyk-Bryłka, 2012, s. 313). Tylko w takich warunkach możliwe są zmia-
Przegląd Organizacji, Nr 11(970), 2020, s. 18-26

www.przegladorganizacji.pl

๑ Towarzystwo Naukowe Organizacji i Kierownictwa (TNOiK) ny w kierunku nowych rozwiązań zachęcających do zaangażowania pracowników w podejmowane decyzje oraz działań mających wpływ na wykonywaną pracę.

W 2019 roku w ówczesnej Katedrze Infrastruktury Zarządzania Politechniki Wrocławskiej (obecnie, po reorganizacji struktur organizacyjnych Uczelni, Katedra nosi nazwę Organizacji i Zarządzania) przeprowadzono badania ankietowe dotyczące przesłanek zaufania, które wynikają z przyjętej przez przedsiębiorstwo polityki personalnej. Wykazano w nich, że spójność polityki personalnej przedsiębiorstwa wyrażana poprzez wizję, system wartości i jasne procedury w sferze kadrowej, wzmacnia zaufanie w ocenie efektów (stanów postrzegania przez pracowników) tej polityki (Świda, Burdzy, 2020). Wyniki uzyskane na podstawie ankiety zawierały 84 stwierdzenia przypisane do 11 pól, w większości związanych z funkcją personalną (Król i in., 2014, s. 5). Wyniki te pozwalają na sformułowanie oceny warunków sprzyjających praktycznej realizacji idei E w dwóch perspektywach wynikających $\mathrm{z}$ wyodrębnionych tamże grup respondentów, to jest: $\mathrm{z}$ perspektywy globalnego przedsiębiorstwa, w którym prowadzono badania, oraz uśrednionej wartości (diagnozy) sformułowanej na podstawie wypowiedzi respondentów $\mathrm{z}$ innych przedsiębiorstw. Uzyskanie takiej oceny jest podstawowym celem niniejszej pracy.

Wybranym do badań podmiotem było znane globalne przedsiębiorstwo handlowe, które deklarowało profesjonalizm w kształtowaniu polityki personalnej ${ }^{1}$. Respondenci, pracownicy tego przedsiębiorstwa to reprezentacja pokolenia $\mathrm{Y}$ w liczbie $\mathrm{N}_{1}=32$ stanowiąca pierwszą grupę respondentów (oznaczoną jako grupa G1). Drugą grupę respondentów, oznaczoną jako grupa G2, stanowili pracownicy z 50 innych organizacji (nie obowiązywały tu ograniczenia wiekowe). Grupa ta tworzyła $z$ natury rzeczy zróżnicowaną (uśrednioną) perspektywę oceny $\left(\mathrm{N}_{2}=50\right)$. Do potrzeb przyjętego celu pracy wyodrębniono, wykorzystując wspomniane wymiary tej koncepcji (traktując je jako filtr diagnostyczny), takie stwierdzenia, które opisują sytuację wyrażającą istotę i/lub warunek wdrażania koncepcji E. Przy wyborze stwierdzeń zachowano świadomość o możliwości istnienia stereotypów (mitów) utrwalanych latami w tym przedmiocie (Marquet, 2015).

Wybór stwierdzeń wykorzystanych na użytek niniejszej pracy ma walory propozycji sformułowanej przez autorów pracy. Odnoszą się one do wszystkich czterech 
obszarów funkcji personalnej, to jest: doboru, motywowania, oceniania i rozwoju oraz do stwierdzeń wybranych na potrzeby kształtowania wizerunku employement branding (EB). Liczbę wyodrębnionych stwierdzeń w poszczególnych polach ankiety wykorzystanych do oceny wspierania warunków charakterystycznych dla realizacji koncepcji E podano w tabeli 5 .

W związku z przyjętym celem pracy, to jest określenie oceny warunków sprzyjających praktycznej realizacji idei E w organizacjach, sformułowano pytanie badawcze: czy spójna polityka personalna wybranego przedsiębiorstwa wykazana (przez grupę G1) w badaniach wyjściowych w stopniu wyższym przygotowuje (wspiera) tę organizację we wdrażaniu E, niż ma to miejsce w organizacjach reprezentowanych przez grupę G2. Pamiętać przy tym należy, że istniała różnica wieku wśród respondentów grup G1 i G2, a wcześniejsze ustalenia wynikające z badań A. Lee, S. Willisa i W. Tiana (2018), obejmujących próbę 105 eksperymentów na temat skłonności przedsiębiorstw do stosowania koncepcji E przeprowadzonych w 30 krajach, wykazały, że akceptacja tej koncepcji jest wyraźnie skorelowana $\mathrm{z}$ wiekiem $\mathrm{i}$ jest wyższa dla reprezentantów z grupy młodszych pracowników.

We wstępnym etapie badań wyjściowych (dotyczących zaufania) wykazano spójność polityki personalnej badanego przedsiębiorstwa (Świda, Burdzy, 2020), korzystając z narzędzia o nazwie Denison Organizational Culture Scale (wg 5-stopniowej skali Likerta) (Juchnowicz i in., 2018, s. 243) oraz wskazano na brak warunków sprzyjających występowaniu sytuacji patologicznych na okoliczność budowania zaufania $\mathrm{w}$ tej organizacji. Posłużono się tu wytycznymi pochodzącymi z literatury przedmiotu (Grudzewski i in., 2009, s. 26; Marquet, 2015; Palka, Winkler, 2006, s. 27; Sankowska, 2011, s. 143).

Wyniki wstępnego etapu badań zaowocowały wyodrębnieniem kilka stwierdzeń mogących konstytuować warunki wdrażania koncepcji E, co pokazano w tabeli 4 . Zinterpretowano je w kontekście przyjętego celu pracy na końcu części związanej z analizą statusu wybranej Spółki w zakresie polityki personalnej, opisanej przez przyjęty na potrzeby analizy model kompetencyjny, podobnie jak i w części drugiej pracy nawiązującej do wybranych kontekstów zaufania. W części trzeciej pracy dokonano analizy miar rozproszenia danych związanych z wyróżnionymi stwierdzeniami konstytuującymi koncepcję E w obrębie funkcji personalnej oraz sformułowano wnioski adresowane do pytania, czy spójna polityka personalna wybranego do badań przedsiębiorstwa wykazana w badaniach wyjściowych (w obrębie Grupy G1) w stopniu wyższym wspiera tę organizację we wdrażaniu E, niż ma to miejsce w przypadku organizacji reprezentowanych przez grupę G2.

\section{Ocena polityki personalnej wybranego przedsiębiorstwa}

W ybrane do badań przedsiębiorstwo handlowe ma swoje placówki (markety) w całej Europie. Na rynku polskim działa od blisko dwudziestu lat. Obecnie funkcjonuje 210 marketów, zatrudniających w swoich strukturach około 17 tysięcy pracowników. W 2017 roku Spółka zajmowała szóstą pozycję w rankingu największych sieci handlowych w Polsce, osiągając przychody rzędu 10,1 miliarda złotych (Business Insider Polska, 2017, s. 5-10). Centrala Spółki mieści się we Wrocławiu, a organizacyjnie przyjęła ona nazwę Centrum Usług Wspólnych (CUW). Respondenci z grupy G1 (32 osoby) pochodzą z Centrum CUW. Są to pracownicy na stanowiskach specjalistów (75\%), kierowniczych i dyrektorskich $(19 \%)$ oraz stażystów aplikujących na stanowiska specjalistyczne $(6 \%)$.

Fundamentalnymi wartościami przestrzeganymi w Spółce są: efektywność (przesądzająca o sukcesie), dynamika (wpływająca na skuteczność w działaniu) i etyka (opierająca się na szacunku, uznaniu, zaufaniu i uczciwości). Na tych trzech podstawowych wartościach sformułowane są zasady zarządzania Spółki, traktowane jako jej zobowiązanie wobec pracowników. Stanowią je: jasna komunikacja i wytyczanie kierunków, rozwój pracowników i wykorzystanie ich potencjału, efektywność i dynamiczne działanie, postępowanie fair i budowanie zaufania, odpowiedzialne działanie i bycie wzorem. Zasady te są wymagane i niezbędne w przypadku efektywnego wdrażania koncepcji E.

Podstawą polityki personalnej badanej Spółki jest przyjęty model kompetencyjny. Model ten umożliwia przełożenie przyjętych wartości i zasad na konkretne zachowania i postawy. Składa się z czterech podstawowych osi kompetencji: osobowościowych, analitycznych, społecznych i kierowniczych (warstwa 1), w drugiej warstwie występuje 11 pól, a trzecia warstwa wskazuje szczegółowe przesłanki (3 lub 4) dla danego pola. Na przykład, w ramach kompetencji kierowniczych wyróżnia się obszar szczególny dla koncepcji E pod nazwą delegowanie zadań i odpowiedzialności z trzema przesłankami: zapewnienie warunków sprzyjających realizacji celów, delegowanie, monitorowanie powierzonych zadań.

Inny obszar modelu kompetencyjnego wzmacniający koncepcję E, występujący pod nazwą tworzenie pozytywnej atmosfery pracy, wyróżnia trzy elementy: motywowanie pracowników, inspirowanie pracowników swoją postawą oraz budowanie kultury uczenia się². Ocena praktyki (uwagi co do stosowania modelu kompetencyjnego) wymagała sprawdzenia, na ile postrzegane i przestrzegane są przez pracowników Spółki wewnętrzne zasady, wartości i założenia modelu kompetencyjnego. W związku z tym zidentyfikowano opinie i zbadano uwagi pracowników wobec dziewięciu stwierdzeń w skali od 1 do 5 ( 1 - zdecydowanie nie, 5 - zdecydowanie tak), nawiązujące do modelu kompetencyjnego (Juchnowicz i in., 2018 , s. 243). Tabela 1 prezentuje stwierdzenia i wyniki uzyskane w badaniu.

W świetle powyższych wyników uznano, że status Spółki jako organizacji posiadającej spójną wizję i politykę personalną w kontekście przyjętego modelu kompetencyjnego nie budzi zastrzeżeń. Wsparciem dla tego statusu jest ocena stwierdzeń determinujących sytuacje patologiczne (zagrożenia - patologie dla zaufania). W pełnym 
wymiarze oceny tego problemu opracowano 21 takich stwierdzeń w ramach trzech kontekstów: względem przełożonego (7 stwierdzeń), względem współpracowników (8 stwierdzeń) oraz względem własnej osoby (6 stwierdzeń). Z badań ankietowanych wynika, że średnia ocena dla sytuacji (stwierdzeń) odnośnie do patologii w zakresie zaufania w Spółce oraz w innych badanych organizacjach w grupie G1, wynikająca z ograniczonego poziomu lub braku zaufania, wyniosła 1,48.
Należy podkreślić rolę trzech stwierdzeń nawiązujących do istoty koncepcji E pod nazwą - brak reakcji na nowe inicjatywy. Te ewentualne niekorzystne sytuacje oceniono w grupach G1 i G2: wobec przełożonego - odpowiednio 1,4 i 2,41 (Mój przełożony wykazuje opór wobec nowych inicjatyw podejmowanych przeze mnie/mój zespół), względem współpracowników - odpowiednio 1,43 i 2,38 (Moi współpracownicy wykazują opór wobec nowych inicjatyw podejmowanych przeze mnie/ mój zespół) oraz

Tabela 1. Postać stwierdzeń i wyniki dla pomiaru: spójność zasad i wartości w Spółce

\begin{tabular}{|c|c|c|c|}
\hline Czynnik & $\mathrm{Nr}$ w ankiecie & Stwierdzenie & Średnia ocen \\
\hline \multirow{3}{*}{ Kluczowe wartości } & 3.1.1. & $\begin{array}{l}\text { Kadra zarządzająca i menedżerowie postępują zgodnie } \\
\text { z kluczowymi zasadami ustanowionymi dla całej organizacji. }\end{array}$ & 4,06 \\
\hline & 3.1 .2 & $\begin{array}{l}\text { W tej organizacji występuje zgodność pomiędzy kluczowymi } \\
\text { wartościami a działaniami biznesowymi (określonymi w tych } \\
\text { wartościach). }\end{array}$ & 4,31 \\
\hline & 3.1.3. & $\begin{array}{l}\text { W tej organizacji istnieją kodeksy etyczne i wskazówki, jak } \\
\text { należy zachowywać się w sytuacjach dylematów etycznych. }\end{array}$ & 3,72 \\
\hline \multirow{3}{*}{ Zgodność } & 3.2 .1 & $\begin{array}{l}\text { W tej organizacji w sytuacjach pojawienia się nieporozumień } \\
\text { pracujemy wspólnie nad znalezieniem optymalnych rozwiązań } \\
\text { satysfakcjonujących wszystkie strony konfliktu. }\end{array}$ & 4,03 \\
\hline & 3.2 .2 & $\begin{array}{l}\text { W tej organizacji raczej łatwo osiągamy consensus, nawet } \\
\text { w trudnych i skomplikowanych sprawach. }\end{array}$ & 3,75 \\
\hline & 3.2.3. & $\begin{array}{l}\text { W naszej organizacji mamy zazwyczaj trudności w znalezieniu } \\
\text { wspólnych rozwiązań.* }^{*}\end{array}$ & 3,94 \\
\hline \multirow{3}{*}{ Koordynacja i integracja } & 3.3.1. & $\begin{array}{l}\text { W tej firmie pracownicy z różnych oddziałów mają podobną } \\
\text { perspektywę patrzenia na organizację i działania firmy. }\end{array}$ & 4,03 \\
\hline & 3.3.2. & $\begin{array}{l}\text { W tej firmie nie ma większych trudności w koordynowaniu } \\
\text { projektów i działań realizowanych przez pracowników z różnych } \\
\text { działów i jednostek organizacyjnych. }\end{array}$ & 4,19 \\
\hline & 3.3.3. & $\begin{array}{l}\text { W mojej firmie istnieją wspólne cele dla pracowników z różnych } \\
\text { szczebli organizacji. }\end{array}$ & 4,41 \\
\hline
\end{tabular}

* Kodowane w odwrotny sposób

Źródto: opracowanie na podstawie wyników z ankiety zgodnie z wytycznymi - wg propozycji M. Juchnowicz i in., 2018, s. 244

Tabela 2. Wyniki i wskaźniki zaufania wg CBOS uzyskane dla grup G1 i G2

\begin{tabular}{|l|c|c|}
\hline \multicolumn{1}{|c|}{ Struktura postaw wg metodyki CBOS (wyraz liczbowy postawy) } & $\begin{array}{c}\text { G1 ( Spółka) } \\
\text { [\%, (liczba osób)] }\end{array}$ & $\begin{array}{c}\text { G2 } \\
\text { [\%, (liczba osób)] }\end{array}$ \\
\hline Bardzo duża ufność, otwartość (+3) & $34,(11)$ & $36,(18)$ \\
\hline Średnia ufność (+2) & $3,(1)$ & $14,(7)$ \\
\hline Niewielka ufność (+1) & $16,(5)$ & $16,(8)$ \\
\hline Ambiwalentna (0) & $0,(0)$ & $0,(0)$ \\
\hline Niewielka nieufność (-1) & $25,(8)$ & $10,(5)$ \\
\hline Średnia nieufność (-2) & $13,(4)$ & $12,(6)$ \\
\hline Bardzo duża nieufność, ostrożność (-3) & $9,(3)$ & $12,(6)$ \\
\hline Średnia ważona, wskaźnik ogólny & 0,44 & 0,79 \\
\hline \multicolumn{2}{|c|}{ Poziom ogólnopolski zaufania w społeczeństwie i biznesie w 2017 r. } \\
\hline
\end{tabular}

Źródto: opracowanie według metody CBOS 2018, s. 5 
wobec siebie - odpowiednio 1,23 i 1,79 (Jestem niezaangażowany w pracę i spełnianie swoich obowiązków.). Dla grupy G2 uzyskano zatem średnie oceny znacząco wyższe (Świda, Burdzy, 2020). Taka pozytywna sytuacja w Spółce pozwoliła na szczegółową analizę stwierdzeń w innych polach polityki personalnej (krok drugi postępowania) $\mathrm{z}$ punktu widzenia sprzyjania koncepcji $\mathrm{E}$.

\section{Pomiar kontekstów zaufania w badaniach wyjściowych}

D

o potrzeb badania przesłanek zaufania organizacyjnego arkusz ankiety podzielono na dziesięć pól, w których oceniano różne konteksty dla problemu zaufania w grupach G1 i G2, w tym pole dotyczące spójności polityki personalnej wyłącznie dla grupy G1. Odrębnie dokonano również pomiaru ogólnego zaufania według metodyki CBOS (ocena 3 stwierdzeń). Stanowi on pewną charakterystykę profilu respondentów uczestniczących w badaniach nie nawiązując do zaufania organizacyjnego. Wyniki podano w tabeli 2.

Otrzymane wskaźniki w obu grupach były jednoznacznie wyższe i dodatnie $(0,44 ; 0,79)$ w porównaniu do wyników uzyskanych na próbie ogólnopolskiej uzy- skanej przez CBOS $(0,89)$. W tym ostatnim przypadku interpretuje się wynik jako poziom wskazujący na ogólną społeczną nieufność Polaków (Lee i in., 2018). Badane dwie grupy G1 i G2 wykazały postawy odmienne z tendencją do wyrażania niewielkiej ufności. Były to poziomy wyższe niż wskaźniki uzyskane dla miast powyżej 500 tys. mieszkańców $(0,24)$ i specjalistów z wyższym wykształceniem $(0,01)$, które to cechy dominują w próbie badawczej (CBOS, 2018, s. 5). Strukturę wieku i stażu obu grup zawiera tabela 3.

Ogólną strukturę (w grupie G1) uzyskaną na podstawie liczby stwierdzeń i pytań dla wszystkich 11 pól wyodrębnionych w badaniach wyjściowych dotyczących przesłanek zaufania, ujmuje tabela 4 . W kolumnie 3 tabeli wskazano liczbę wyodrębnionych stwierdzeń na potrzeby oceny warunków do wspierania i wdrożenia E. Łącznie występują one w dziewięciu polach. Sześć pól nawiązuje do funkcji personalnej i wizerunku EB (liczby pogrubione) oraz trzy wynikające z innego, ogólniejszego kontekstu.

W ocenie polityki personalnej w kontekście warunków służących wdrożeniu koncepcji Empowermentu skoncentrowano się, jak wspomniano, na sześciu polach, w których wyodrębniono 18 stwierdzeń konstytuujących ewentualne

Tabela 3. Struktura wiek/staż w dwóch grupach respondentów

\begin{tabular}{|c|c|c|c|c|}
\hline $\begin{array}{c}\text { Wiek/staż (lat/lat) } \\
\text { Respondenci }\end{array}$ & $\mathbf{1 8 - 2 4 / \text { do 5 }}$ & $\mathbf{2 5 - 3 4 / 6 - 1 5}$ & $\mathbf{3 5 - 4 4 / 1 6 - 2 5}$ & $\mathbf{4 5 - 6 4 / 2 6 +}$ \\
\hline $\begin{array}{c}\text { Grupa 1 (pracownicy centrali } \\
\text { spółki) - ---32 osoby [\%/\%] }\end{array}$ & $9 / 31$ & $53 / 66$ & $38 / 3$ (max staż 17 lat) & $0 / 0$ \\
\hline $\begin{array}{c}\text { Grupa 2 (pracownicy z innych } \\
\text { przedsiębiorstw) - 50 osób [\%/\%] }\end{array}$ & $18 / 28$ & $34 / 36$ & $16 / 12$ & $32 / 24$ \\
\hline
\end{tabular}

Źródło: badania ankietowe

Tabela 4. Struktura kwestionariusza zastosowanego w badaniach

\begin{tabular}{|l|c|c|}
\hline \multicolumn{1}{|c|}{ Nazwa pola } & $\begin{array}{c}\text { Liczba stwierdzeń } \\
\text { w polu }\end{array}$ & $\begin{array}{c}\text { Liczba stwierdzeń do } \\
\text { oceny empowermentu }\end{array}$ \\
\hline 1. Ogólny poziom zaufania (CBOS) & 3 (pytania) & 2 \\
\hline $\begin{array}{l}\text { 2. Ogólne kryteria i zasady zaufania w środowisku pracy wg wskazań literatury } \\
\text { przedmiotu }\end{array}$ & $\mathbf{9}$ & 3 \\
\hline 3. Ogólne sytuacje wskazujące na ograniczenia/ brak zaufania (patologie) & 21 & 1 \\
\hline 4. Sytuacje wzmacniające zaufanie w doborze pracowników & $\mathbf{5}$ & 6 \\
\hline 5. Sytuacje wzmacniające zaufanie w motywowaniu pracowników & $\mathbf{1 1}$ & 2 \\
\hline 6. Sytuacje wzmacniające zaufanie w ocenie pracowników & 9 & 4 \\
\hline 7. Sytuacje wzmacniające zaufanie w rozwoju pracowników & $\mathbf{5}$ & 4 \\
\hline 8. Sytuacje przekrojowe w funkcji personalnej & 10 & 1 \\
\hline 9. Sytuacje wzmacniające zaufanie w wizerunku pracodawcy & 5 & 2 \\
\hline 10. Sytuacje wzmacniające pozytywny klimat organizacyjny & $\mathbf{8}$ & $\mathbf{9}$ \\
\hline 11. Denison Organizational Culture Scale - wymiar spójności organizacyjnej & & - \\
\hline
\end{tabular}

Źródto: opracowanie wtasne 
wdrożenie koncepcji E (liczby pogrubione w tabeli 4). W trzech pozostałych polach analizowano stwierdzenia wyłącznie pod kątem uzyskania wysokiej progowej wartości (średnia z próby). I tak, dla sytuacji nazwanych patologiami wynosiła ona dla Spółki poniżej 1,5 (kodowanie odwrotne, ocena na końcu części 1), dla dwóch pozostałych pól co najmniej 4,5. I tak, dla pola nr 2 średnia z dwóch wyróżnionych stwierdzeń wpisanych do koncepcji E dla Spółki wynosiła 4,53. W polu nr 10 (tab. 4) średnia dla charakterystycznych (dla E) stwierdzeń (1. Pracownicy udzielają pomocy i informacji współpracownikom, gdy tego potrzebują. 2. Pracownicy wymieniają się informacjami, wiedzą, pomysłami) wynosiła 4,47, przy czym mediana i dominanta w obu przypadkach wynosiły 5,0 , co dało powody do pozytywnego - jak wspomniano - zaakceptowania sytuacji. odnośnie do spójności polityki personalnej Spółki w kontekście postawionego pytania badawczego. Wyniki ankiety poddano weryfikacji statystycznej co do rzetelności za pomocą wyznaczenia współczynnika Alfa Cronbacha (program IMB SPSS Statistics) dla czterech części kwestionariusza. Wyniki analizy podane są w tabeli 5 .
Oznacza to, że uwzględnione $\mathrm{w}$ ankiecie wyniki są spójne co do przyjętych stwierdzeń, w tym tych, wyodrębnionych na potrzeby oceny warunków koniecznych do wspierania i wdrożenia (wykorzystania w praktyce) koncepcji E.

\section{Analiza warunków wspierania i wdrożenia koncepcji empowerment}

A naliza ta jest kluczowa dla postawionego pytania badawczego. Z wcześniejszych ustaleń wynika, że dotyczy ona 18 stwierdzeń ankiety z sześciu pól (4-9) podanych w tabeli 4 (liczby pogrubione). Wybrane stwierdzenia wychwytują te sytuacje z badań przesłanek zaufania, które w koncepcji E są eksponowane w ramach wymiarów upełnomocnienia: self-eficiency (poczucie kompetencji do wykonywania samodzielnych, innowacyjnych zadań), self-determination (poczucie samodzielności do działania i ponoszenia odpowiedzialności), personal conseqency (poczucie wywierania wpływu na procesy i osoby poprzez skuteczną komunikację), meaning (poczucie wartości

Tabela 5. Ocena rzetelności kwestionariusza na podstawie współczynnika Alfa Cronbacha

\begin{tabular}{|l|c|c|}
\hline \multicolumn{1}{|c|}{ Część kwestionariusza } & $\begin{array}{c}\text { Współczynnik Alfa Cronbacha } \\
\text { inne organizacje }\end{array}$ & $\begin{array}{c}\text { Współczynnik Alfa Cronbacha } \\
\text { Spółka }\end{array}$ \\
\hline 1. Spójność kultury organizacyjnej (pole 11) & 0,873 & 0,720 \\
\hline 2. Aspekty teoretyczne zaufania/braku zaufania (pole 2) & 0,919 & 0,873 \\
\hline 3. Sytuacje związane z brakiem zaufania-patologie (pole 3) & 0,968 & 0,921 \\
\hline 4. Zaufanie w obszarach funkcji personalnej (pola 4-10) & 0,905 & 0,955 \\
\hline Całościowo & 0,971 & \\
\hline
\end{tabular}

Źródto: wyniki uzyskane z użyciem programu IBM SPSS Statistics

Tabela 6. Miary rozproszenia dla stwierdzeń nawiązujących do wymiarów upełnomocnienia

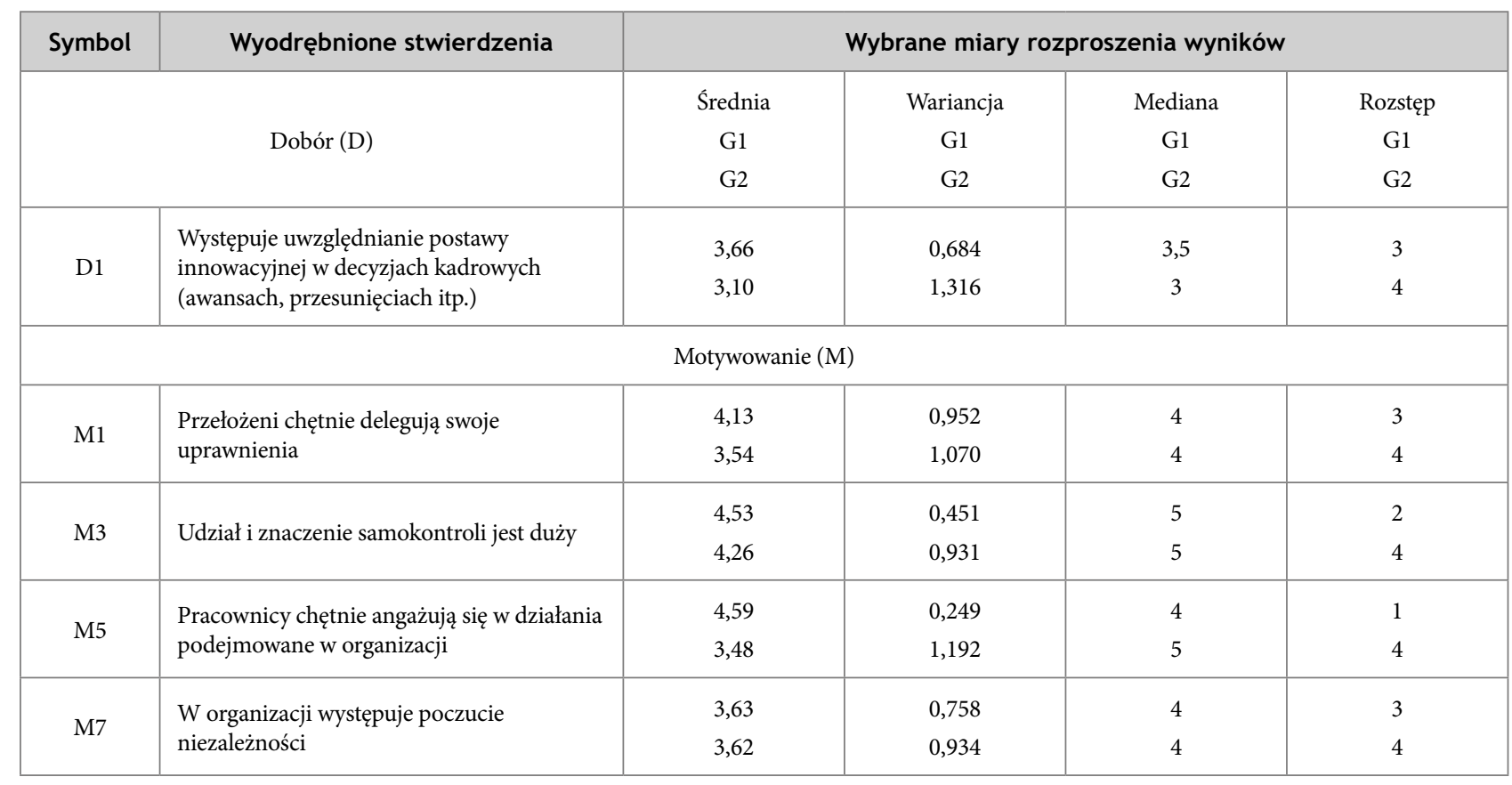




\begin{tabular}{|c|c|c|c|c|c|}
\hline Symbol & Wyodrębnione stwierdzenia & \multicolumn{4}{|c|}{ Wybrane miary rozproszenia wyników } \\
\hline \multirow{2}{*}{ M8 } & \multirow{2}{*}{$\begin{array}{l}\text { Występuje poczucie możliwości wpływania } \\
\text { na bieg spraw w organizacji }\end{array}$} & 3,22 & 1,080 & 4 & 3 \\
\hline & & 3,46 & 0,949 & 3 & 4 \\
\hline \multirow{2}{*}{ M10 } & \multirow{2}{*}{$\begin{array}{l}\text { Występuje poczucie, że wysiłek } \\
\text { i zaangażowanie zyskują uznanie }\end{array}$} & 4,1 & 0,975 & 4 & 3 \\
\hline & & 3,506 & 1,602 & 4 & 4 \\
\hline & \multirow{2}{*}{ Średnia dla obszaru M } & 4,03 & & & \\
\hline & & 3,65 & & & \\
\hline \multicolumn{6}{|c|}{ Ocenianie $(\mathrm{O})$} \\
\hline \multirow{2}{*}{$\mathrm{O} 1$} & \multirow{2}{*}{$\begin{array}{l}\text { Istnieją liczne formuły bezpośrednich } \\
\text { kontaktów z przełożonymi }\end{array}$} & 4,16 & 0,652 & 4 & 3 \\
\hline & & 3,90 & 0,908 & 4 & 3 \\
\hline \multirow{2}{*}{ O6 } & \multirow{2}{*}{$\begin{array}{l}\text { W systemach ocen zachowania } \\
\text { proinnowacyjne są uwzględniane } \\
\text { i premiowane }\end{array}$} & 2,22 & 1,144 & 2 & 4 \\
\hline & & 3,34 & 1,617 & 3 & 4 \\
\hline & \multirow{2}{*}{ Średnia dla obszaru O } & 3,19 & & & \\
\hline & & 3,62 & & & \\
\hline \multicolumn{6}{|c|}{ Rozwój (R) } \\
\hline \multirow{2}{*}{$\mathrm{R} 1$} & \multirow{2}{*}{$\begin{array}{l}\text { Występuje możliwość nauki nie tylko tego, } \\
\text { co bezpośrednio wiąże się z wymaganiami } \\
\text { stanowiska, ale także doskonalenia innych } \\
\text { umiejętności (np. umiejętności społeczne) }\end{array}$} & 4,03 & 0,805 & 4 & 3 \\
\hline & & 3,86 & 0,858 & 4 & 4 \\
\hline \multirow{2}{*}{ R2 } & \multirow{2}{*}{$\begin{array}{l}\text { Pracownicy znają swoje silne strony } \\
\text { i podejmują zadania, w których mogą te } \\
\text { silne strony wykorzystywać }\end{array}$} & 3,59 & 0,636 & 4 & 3 \\
\hline & & 3,84 & 1,035 & 4 & 4 \\
\hline \multirow[b]{2}{*}{ R3 } & \multirow{2}{*}{$\begin{array}{l}\text { Nie występuje obawa przed } \\
\text { podejmowaniem eksperymentów } \\
\text { w działaniu }\end{array}$} & \multirow{2}{*}{$\begin{array}{l}4,13 \\
3,42\end{array}$} & 0,952 & 4 & \\
\hline & & & 0,983 & 4 & 4 \\
\hline \multirow{4}{*}{ R4 } & \multirow{2}{*}{$\begin{array}{l}\text { Występuje przekonanie o możliwości } \\
\text { wykorzystywania w pracy zainteresowań } \\
\text { oraz rozwijania własnych talentów }\end{array}$} & 3,47 & 0,580 & 4 & 4 \\
\hline & & 3,52 & 1,316 & 4 & 4 \\
\hline & \multirow{2}{*}{ Średnia dla obszaru R } & 3,81 & & & \\
\hline & & 3,66 & & & \\
\hline \multicolumn{6}{|c|}{ Sytuacje przekrojowe dla obszarów D, M, O, R. } \\
\hline \multirow{2}{*}{ P1 } & \multirow{2}{*}{ Występuje pełna argumentacja decyzji } & 3,81 & 1,383 & 4 & 4 \\
\hline & & 3,50 & 1,480 & 4 & 4 \\
\hline P2 & Pracownicy śmiało wypowiadają własne & 4,50 & 1,097 & 5 & 4 \\
\hline 12 & opinie. & 3,90 & 1,071 & 4 & 4 \\
\hline P5 & Występuje poczucie, że procedury i kryteria & 4,22 & 0,499 & 4 & 3 \\
\hline P5 & są przejrzyste & 3,94 & 0,670 & 4 & 3 \\
\hline P7 & Występuje przekonanie o kompetencjach & 4,41 & 0,765 & 5 & 3 \\
\hline & przełożonych & 3,70 & 0,990 & 4 & 4 \\
\hline & Średnia dla obszaru P & 4,24 & & & \\
\hline & & 3,76 & & & \\
\hline & & Nizerun & & & \\
\hline FB1 & Pracownicy wypowiadają się z dumą & 4,24 & 0,588 & 4 & 2 \\
\hline EB1 & o swojej firmie & 3,50 & 1,398 & 4 & 4 \\
\hline & Średnia dla wytypowanych stwierdzeń & $\begin{array}{l}3,92 \\
3,63\end{array}$ & & & \\
\hline
\end{tabular}

Źródło: opracowanie na podstawie danych z ankiet z wykorzystaniem programu SPSS podanego w pracy A. Świda, A. Burdzy (2020) 
- użyteczności swoich działań zgodnych z przyjętą wizją wartości organizacji i klimatem opartej na tej wizji), trust (poczucie braku zagrożeń wobec oceny własnej samodzielności w granicach posiadanych kompetencji). Jak wspomniano, wyodrębnienie stwierdzeń ma autorski charakter.

Podstawą oceny sytuacji dla grup G1 i G2 były miary rozproszenia dla 18 stwierdzeń otrzymanych z programu SPSS. W tabeli 6 ujęto wyniki tych obliczeń. W ostatniej kolumnie nawiązano ponadto do składowej (składowych) empowermentu podanych przez H. Czubasiewicz. i P. Grajewskiego, mogących łączyć się z danym stwierdzeniem w przypadku wdrożenia koncepcji E w praktyce organizacyjnej.

Analizę rozproszenia wyników dla 18 stwierdzeń można odnieść do trzech poziomów agregacji oceny: łącznego: obejmującego poszczególne obszary adresowane do funkcji personalnej (i wizerunku EB), oraz dla konkretnego stwierdzenia.

Dla każdego z poziomów zauważalne są różnice między grupami G1 (Spółka) i G2² . W zagregowanym ujęciu średnia oceny dla 18 stwierdzeń wynosi odpowiednio 3,92 i 3,63. Dla grupy G1 ogólny wynik znacznie zaniża sytuacja O6, która jest także niska w grupie respondentów G2 (odpowiednio 2,22 i 3,34). Dodatkowo widać także, że cały obszar funkcji - stwierdzeń pod nazwą ocenianie - został również wyceniony najniżej, to jest 3,89. Obejmował on w badaniach wyjściowych dziewięć stwierdzeń (tab. 4) dotyczących między innymi, cech kryteriów oceny (jasne, wymierne, obiektywne). Jest to trudny do wysokiej akceptacji przez pracowników obszar w praktyce, co miało miejsce w wielu organizacjach (Bugara, 2016, s. 44).

Odnosząc się do innych badanych obszarów funkcji personalnej, wyższa łączna ocena (średnia) dla Spółki dotyczy wszystkich obszarów oraz wizerunku. Stosunkowo prosta sytuacja dotyczy doboru (D) i wizerunku (EB) z uwagi na pojedyncze wytypowane stwierdzenia. W dwóch obszarach rozwój (R) i motywowanie (M) mimo wyższego dla Spółki wyniku łącznego są takie stwierdzania, wobec których uzyskano zróżnicowane i relatywnie niskie wyceny. Sprawia to, że wnioski nie są już tak jednoznaczne. Na przykład w obszarze rozwoju wynik R3 $(4,13)$ może sugerować wyższą postrzeganą samodzielność pracowników Spółki w stosunku do innych organizacji. Z kolei wynik R2 i R4 dla G1 (odpowiednio 3,59 i 3,47) związany z poczuciem self-eficiency i self-determination jest niski i niższy niż w G2 (odpowiednio 3,84 i 3,52). Interesująca sytuacja występuje w przypadku stwierdzeń D1 i EB1. W pierwszym przypadku obraz przesłanek proinnowacyjnych w rozwiązaniach kadrowych (wewnętrznych) nie jest wysoko wyceniony w obu grupach (G1 - 3,66 i G2 - 3,10). W drugim przypadku potencjał wizerunkowy Spółki jest znacznie wyższy niż średni potencjał innych organizacji (G1 - 4,24 i G2 - 3,50). Również obszar motywowania, w którym występują sytuacje typowe dla wdrożenia koncepcji E nie jest, jak wspomniano, jednoznaczny. Średnie dla M7 (G1 - 3,63 i G2 - 3,62) oraz M8 (G1 - 3,22 i G2 - 3,46) nie są korzystne dla Spółki i respondentów z innych organizacji. Z kolei postrzeganie delegowań uprawnień (M1) oraz samokontrola (M3) osiągnęły dla Spółki wysoki poziom (odpowiednio 4,13 oraz 4,53).
Reasumując wyniki uzyskane dla stwierdzeń nawiązujących do E w ramach badań zaufania, należy podkreślić syntetyzujący wniosek z badań, iż poczucie pracowników Spółki wynikające ze stanu ich upełnomocnienia nie jest jednoznacznie pozytywne, jednak nieco wyższe niż w grupie G2 (Malara, Kroik, 2016). Skłania to do zachowania ostrożności w udzieleniu odpowiedzi na postawione pytanie przy świadomości, że wprowadzenie zasad koncepcji E do polityki personalnej wymaga odrębnych prac koncepcyjnych i wdrożeniowych. Tym samym można sformułować wniosek, że badana Spółka posiada wprawdzie spójną wizję, wartości i wyznaczony model kompetencyjny, lecz nie prowadzi świadomej polityki personalnej zbliżonej do wymogów koncepcji E. Świadomość reguł tej koncepcji przez menedżerów nie jest jednak powszechnie rozpoznawalna $\mathrm{z}$ uwzględnieniem zapisów (kryteriów) literatury przedmiotu (Krawczyk-Bryłka, 2012, s. 313), co utrudnia jej wdrażanie w praktyce.

\section{Podsumowanie}

D odstawową konkluzją jest to, że wybrana do badań organizacja, która w porównaniu do innych organizacji osiągnęła wyraźnie korzystny wynik dla źródeł zaufania, potwierdziła tylko w ograniczonym zakresie stan przewagi z perspektywy założeń odnoszących się do charakterystyki koncepcji E. Zastosowany filtr dla stwierdzeń (kryteria oceny) uwzględniający pięć wymiarów E - unaocznił, że warstwa polityki personalnej w zakresie poczucia upełnomocnienia nie jest na poziomie jednoznacznie wyższym, niż ma to miejsce w przypadku innych organizacji. Za taką refleksją co do praktyki wdrażania $\mathrm{E}$ przemawiają ustalenia $\mathrm{z}$ innych prac. Przykładowo, w powoływanym artykule (Czubasiewicz, Grajewski, 2018, s. 163) zaproponowano cztery stopnie oceny realiów organizacyjnych w zakresie upełnomocnienia. Mogą one dotyczyć części lub całej organizacji. Najniższy stan (0) to brak upełnomocnienia, czyli skoncentrowanie decyzji na wysokim szczeblu organizacji. Drugi stan określony jako upełnomocnienie ograniczone (1), tworzone sytuacyjnie, ale bez jasnych sytuacji formalnych, oparte na indywidualnych predyspozycjach. W takich warunkach tworzy się z reguły poczucie samodzielności i odpowiedzialności za procesy, mimo formalnie ograniczonego wpływu na nie. Poziomy (2) i (3) tzw. stabilizacyjne i adaptacyjne mają charakter sformalizowany. Sytuację zarejestrowaną w CUW należy wiązać z poziomem (1). Tłumaczy to niejednoznaczność uzyskanych wyników w wycenie wyróżnionych 18 stwierdzeń dla koncepcji E. W artykule tym część postulatywna skoncentrowana jest na organizacjach działających w oparciu o projekty. Dla takich organizacji opracowano szczegółowe wytyczne diagnostyczne charakteryzujące ww. cztery poziomy dla 9 kontekstów organizacyjnych.

Wybrane przedsiębiorstwo globalne nie stosuje podejścia projektowego, mimo że sam odcinek organizacyjny CUW może w przyszłości je wykorzystywać. Dlatego też przy wycenie aktualnego poziomu upełnomocnienia (poziom 1) ograniczono się do wstępnej interpretacji wyników. Zachęceniem do wdrożenia koncepcji E w Spółce mogą być wyniki oceny 105 badań z 30 krajów. Wykazano w nich, że istnieje pozytywna korelacja wdrażania koncepcji E z ich wynikami 
ekonomicznymi nawet dla działań (operacji) rutynowych (Lee i in., 2018). Korelacja jest jednak niższa niż w przypadku działań charakterystycznych do podejścia projektowego w zarządzaniu organizacją.

Odpowiedź na postawione we wprowadzeniu pytanie badawcze nie może być więc jednoznacznie pozytywna. Okazuje się bowiem, że nawet wysoki poziom przesłanek (źródeł) dla zaufania w Spółce posiadającej spójną politykę personalną nie tworzy jeszcze warunków dla pojawienia się sytuacji z wysokim poziomem dla wszystkich wymiarów E. Można przyjąć przypuszczenie, że sama kultura zaufania, bez wsparcia ukierunkowanych działań organizacyjnych według pięciu wspominanych we wstępie składników E (co ujęto też w ostatniej kolumnie tabeli 6) nie wystarcza do przejścia na poziom 2 i, co najwyżej ewoluuje wokół poziomu 1, tak jak ma to prawdopodobnie miejsce w Spółce (CUW).

W artykule H. Czubasiewicz i M. Grajewskiego (2018, s. 72) postuluje się zastosować odpowiednie narzędzie diagnostyczne (ankietę) do oceny poziomu empowermen$t u$, tak aby uchwycić kontekst (czynniki) psychologiczny, społeczny, kompetencyjny i komunikacyjny pracowników. Za tym działaniem powinno się kryć przekonanie kierownictwa do koncepcji E, koncepcji, która poprzez rozwój samodzielności pracowników ma wyzwalać twórczość i zaangażowanie pracowników będące drogą do realizacji celów strategicznych organizacji (Skonieczny, 2019, s. 187). Tworzą one (twórczość i zaangażowanie) innowacyjny nośnik modeli biznesowych. Rola zaufania jest kluczowa, ale w świetle powyższych analiz nie jest wystarczająca, aby można mówić o gwarancji do urzeczywistnienia w praktyce koncepcji E. Konieczne wydaje się więc podjęcie dodatkowego wysiłku o charakterze badań retrospektywnych o rozwiniętym kontekście badawczym, zarówno w odniesieniu do próby, jak i zakresu, w celu petryfikacji uzyskanych ustaleń. Tymczasem trudno o jednoznaczną interpretację uzyskanych wyników, a co za tym idzie, sformułowanie arbitralnych rekomndacji. Najwłaściwszym sędzią w tej mierze pozostają czas i rzeczywistość organizacyjna, które pozwolą na weryfikację ustaleń autorów.

\section{prof. dr hab. inż. Zbigniew Malara \\ Politechnika Wrocławska \\ Wydział Informatyki i Zarządzania \\ ORCID: 0000-0002-4404-4959 \\ e-mail: zbigniew.malara@pwr.edu.pl}

\section{dr inż. Janusz Kroik \\ Politechnika Wrocławska \\ Wydział Informatyki i Zarządzania \\ ORCID: 0000-0001-8245-7781 \\ e-mail: janusz.kroik@pwr.edu.pl}

\section{Przypisy}

1) Autorzy pracy nie uzyskali zgody na upublicznianie nazwy podmiotu, w którym prowadzono badania.
2) Na podstawie dokumentów i sprawozdań oraz materiałów udostępnionych przez pracowników Spółki.

3) Zbadano, jako pomocniczy miernik, korelację rang przypisanych średnim ocen w 18 stwierdzeniach. Współczynnik Spearmana $r=0,386$ wskazuje na słabą zależność.

\section{Bibliografia}

[1] Bugara K. (2016), Analiza okresowej oceny pracowników $w$ wybranych przedsiębiorstwach, praca dyplomowa, Wydział Informatyki i Zarządzania Politechniki Wrocławskiej, Wrocław.

[2] Business Insider Polska (2017), Największe sieci handlowe w Polsce w 2017 r. Dyskonty deklasują konkurencję, https:// businessinsider.com.pl/twoje-pieniadze/najwieksze-sieci-handlowe-w-polsce-w-2017-roku/xc8lq0z, data dostępu: $15.10 .2018 \mathrm{r}$

[3] CBOS (2018), Komunikat z badań: O nieufności i zaufaniu, https://www.cbos.pl/SPISKOM.POL/2018/K_035_18.PDF, data dostępu: 20.01.2019 r.

[4] Czubasiewicz H., Grajewski P. (2018), Koncepcja empowermentu $w$ zarządzaniu organizacjami, „Studia i Prace Kolegium Zarządzania i Finansów”, Zeszyt Naukowy 162, s. 153-173.

[5] Gkorezis P., Hatzithomas L., Petridou E. (2001), The Impact of Leader's Humour on Employee's Psychological Empowerment: the Moderating Role of Tenure, „Journal of Managerial Issues", Vol. XXIII, No. 1, pp. 83-95.

[6] Grudzewski W. M., Hejduk I. K., Sankowska A., Wańtuchowicz M. (2009), Zarządzanie zaufaniem w przedsiębiorstwie, Wolters Kluwer, Kraków.

[7] Juchnowicz M., Mazurek-Kucharska B., Turek D. (2018), Diagnoza jakości kapitatu ludzkiego w organizacji. Metody i narzędzia pomiaru, PWE, Warszawa.

[8] Krawczyk-Bryłka B. (2012), Empowerment - strategia zarządzania oparta na zaufaniu, „Zarządzanie i Finanse”, $\mathrm{Nr}$ 4/1, s. 313-330.

[9] Król M., Warzecha A., Zieliński M. (red.), (2014), Funkcja personalna $w$ przedsiębiorstwie. Zakres, pomiar realizacji, uwarunkowania, CeDeWu, Warszawa.

[10] Lee A., Willis S., Tian W. (2018), When Empowering Employees Works and When It Doesn't, https://hbr.org/2018/03/ when-empowering-employees-works-and-when-it-doesnt, access date: 15.01.2019.

[11] Malara Z., Kroik J. (2016), Innowacyjne nośniki modeli biznesu oraz ich obecność w strategii przedsiębiorstwa, [w:] Z. Malara (red.), Oblicza innowacji w gospodarce i społeczeństwie., Oficyna Wydawnicza Politechniki Wrocławskiej, Wrocław, s. 121-136.

[12] Marquet D. (2015), 6 Myths About Empowering Employees, https://hbr.org/2015/05/6mths-about-empowering-employees, access date: 25.10 .2019 .

[13] Palka J., Winkler R. (2006), Bariery budowy kultury zaufania, „Zeszyty Naukowe Akademii Ekonomicznej w Krakowie", Nr 715, s. 27-40.

[14] Sankowska A. (2011), Wplyw zaufania na zarzadzanie przedsiębiorstwem. Perspektywa wewnątrzorganizacyjna, Difin, Warszawa. 
[15] Skonieczny J. (2019), Twórczość jako fundament organizacji, Oficyna Wydawnicza Politechniki Wrocławskiej, Wrocław.

[16] Świda A., Burdzy A. (2020), Spójność polityki personalnej przedsiębiorstwa w perspektywie zaufania, „Zeszyty Naukowe Wyższej Szkoły Humanitas. Zarządzanie”, Nr 3, s. 165-180.

\section{Empowerment in the Light of Studies related to Trust in Organisations}

\section{Summary}

The studies are focused on assessing the organisation's readiness for the implementation of human resources management concept known as Empowerment (E). Earlier research related to premises of trust in a selected global organisation, which has consistent (coherent) personnel policy and - as a reference background - in 50 other organisations allowed to distinguish 18 context (statements in the surveys), that constitute the concept of E. Initially, it was assumed that the selected organisation should reach a higher rate of E-readiness, based on higher rate results of trust in previous studies. A culture of trust is recognised as a necessary condition for E. However, it turned out that the situation filter specific for $\mathrm{E}$, does not place organisation as favourable as in trust research. For the diagnosis of the current state, the proposal of Czubasiewicz and Grajewski was used, to evaluate - on a four-point scale (0-3) - the usage of $E$ in practice. The obtained results indicate that the current state can be associated with level $1-\mathrm{lim}$ ited authorisation. It is characteristic for authorisation cases without clear formal premises, based on individual predispositions. For reference, the results for the selected organisation did not differ significantly from the average E-profile for 50 other organisations.

\section{Keywords}

trust, research, employee, empowerment 